\title{
ЮБИЛЕЙ УЧЕНОГО: ВАДИМУ ВИНЦЕРОВИЧУ ТРЕПАВЛОВУ - 60 ЛЕТ
}

\author{
(c) 2020 г. Канат Ускенбай ${ }^{1}$
}

\author{
${ }^{1}$ кандидат исторических наук, г. Алматы, Казахстан. E-mail: kz.77@inbox.ru
}

\begin{abstract}
Аннотация. В 2020 году доктору исторических наук В.В. Трепавлову исполняется 60 лет. В статье описывается биография и творческий путь ученого. Интерес к истории евразийских кочевников появился у В.В. Трепавлова еще в школьные и студенческие годы, а первым научным результатом стала кандидатская диссертация о социальнополитической преемственности в государственном строе Великой Монгольской империи Чингиз-хана. Его докторская диссертация была посвящена известной истории Ногайской Орды. В Институте российской истории В.В. Трепавлов прошел все ступени карьерного роста, после аспирантуры он работал в должности лаборанта, младшего, старшего, ведущего и главного научного сотрудника, сейчас является руководителем Центра истории народов России и межэтнических отношений. Несколько лет он одновременно занимал должность заместителя директора Института по научной работе. Коротко описываются основные монографические работы юбиляра.

Ключевые слова: Вадим Винцерович Трепавлов, кочевники Евразии, монголы, тюрки, татары, Великая Монгольская империя, Чингиз-хан, Ногайская Орда, Улус Джучи, Золотая Орда, Большая Орда, Сибирский юрт, “Белый царь”, подданство, этническая политика, межэтнические отношения
\end{abstract}

\section{ҒАЛЫМНЫН МЕРЕЙТОЙЫ: ВАДИМ ВИНЦЕРОВИЧ ТРЕПАВЛОВ - 60 ЖАСТА}

\author{
Қанат Өскенбай ${ }^{1}$ \\ ${ }^{1}$ т.ғ.к., Алматы қ., Қазақстан. E-mail: kz.77@inbox.ru
}

\begin{abstract}
Аннотация. 2020 жылы тарих ғылымдарының докторы В. В. Трепавлов 60 жасқа келеді. Мақалада ғалымның өмірбаяны мен шығармашылық жолы суреттеледі. B. В. Трепавловтың еуразиялық көшпенділер тарихына деген қызығушылығы мектеп қабырғасы мен студенттік жылдардан басталған. Ал оның алғашқы нәтижесі Шыңғыс ханның Ұлы Моңғол империясындағы мемлекеттік құрылыстың әлеуметтіксаяси сабақтастығы туралы кандидаттық диссертация болатын. Оның докторлық диссертациясы Ноғай Ордасының тарихына арналған. В. В. Трепавлов Ресей тарихы институтында барлық лауазымдық сатылардан өтіп, аспирантурадан кейін лаборант, кіші, аға, жетекші және бас ғылыми қызметкер болып қызмет жасаған ол бүгінде Ресей халықтары және этникаралық қатынастар тарихы орталығының басшысы. Сонымен қатар бірнеше жыл Институт директорының ғылыми жұмыстар жөніндегі орынбасары болып қызмет атқарды. Мерейтой иесінің басты монографиялық еңбектері де қысқаша суреттелген.

Түйін сөздер: Вадим Винцерович Трепавлов, Еуразия көшпенділері, моңғолдар, түріктер, татарлар, Ұлы Моңғол империясы, Шыңғыс хан, Ноғай Ордасы, Жошы ұлысы, Алтын Орда, Үлкен Орда, Сібір жұрты, “Ақ патша”, бодандық, этникалық саясат, этникаралық қатынастар
\end{abstract}




\title{
ANNIVERSARY OF A SCIENTIST: VADIM V. TREPAVLOV is 60 years old
}

\author{
Qanat Uskenbay ${ }^{1}$
}

${ }^{1}$ Candidate of historical sciences, Almaty, Kazakhstan. E-mail: kz.77@inbox.ru

\begin{abstract}
In 2020, the doctor of historical sciences V. V. Trepavlov turns 60 years old. The article describes the biography and career path of the scientist. Interest in the history of Eurasian nomads appeared in V. V. Trepavlov in his school and student years, and the first scientific result was his Candidate's dissertation on socio-political continuity in the state system of the Great Mongol Empire of Genghis Khan. His doctoral dissertation was devoted to the famous history of the Nogai Horde. At the Institute of Russian History V. V. Trepavlov passed all stages of career growth, after graduate school he worked as a laboratory assistant, junior, senior, leading and chief researcher, now he is the head of the Center for the History of the Peoples of Russia and Interethnic Relations. For several years, he simultaneously served as deputy director of the Institute on scientific work. The main monographic works of the scientist of the day are briefly described.

Keywords: Vadim V. Trepavlov, nomads of Eurasia, Mongols, Turks, Tatars, Great Mongol Empire, Genghis Khan, Nogai Horde, Ulus Juchi, Golden Horde, Big Horde, Siberian Yurt, "Belyi Tsar", citizenship, ethnic politics, interethnic relations
\end{abstract}

Известному российскому ученому главному научному сотруднику - руководителю Центра истории народов России и межэтнических отношений Института российской истории Российской академии наук, доктору исторических наук Вадиму Винцеровичу Трепавлову в 2020 году исполняется 60 лет (рис. 1). За свою без малого сорокалетнюю творческую деятельность Вадим Винцерович прошел большой, достойный глубокого уважения и восхищения путь, сформировавший его как ведущего современного специалиста по истории евразийских кочевников древности, средних веков и нового времени.

Вадим Винцерович Трепавлов родился в 1960 г. в уральском городе Свердловске (ныне Екатеринбург). Интерес к истории кочевых народов средневековой Евразии, как говорил сам Вадим Винцерович в наших личных беседах, появился у него уже в школьные годы, именно тогда он твердо решил посвятить свою жизнь профессиональному ремеслу исто- рика. Это увлечение возникло спонтанно, по до сих пор неведомой ему самому причине. Годы учебы на историческом факультете Уральского государственного университета убедили молодого студента В. В. Трепавлова в правильности выбранного пути. Этому способствовала и хорошая университетская атмосфера. Многое в дальнейшей научной деятельности студентов зависит от первых учителей. Для Вадима Винцеровича таким учителем стала известный тюрколог и археолог профессор Бронислава Борисовна Овчинникова [Ганиев и др., 2012, c. 16]. По словам самого Вадима Винцеровича, она стала его «крестной» в науке [Трепавлов, 2015, с. 9]. На его студенческие годы пришелся период активной научной деятельности Брониславы Овчинниковой - написание кандидатской диссертации «Тюркитугю на Саяно-Алтайском нагорье в VI-X вв.», которую она защитила в 1984 г. в Московском государственном университете им. М. В. Ломоносова и позднее издала на ее основе моно- 


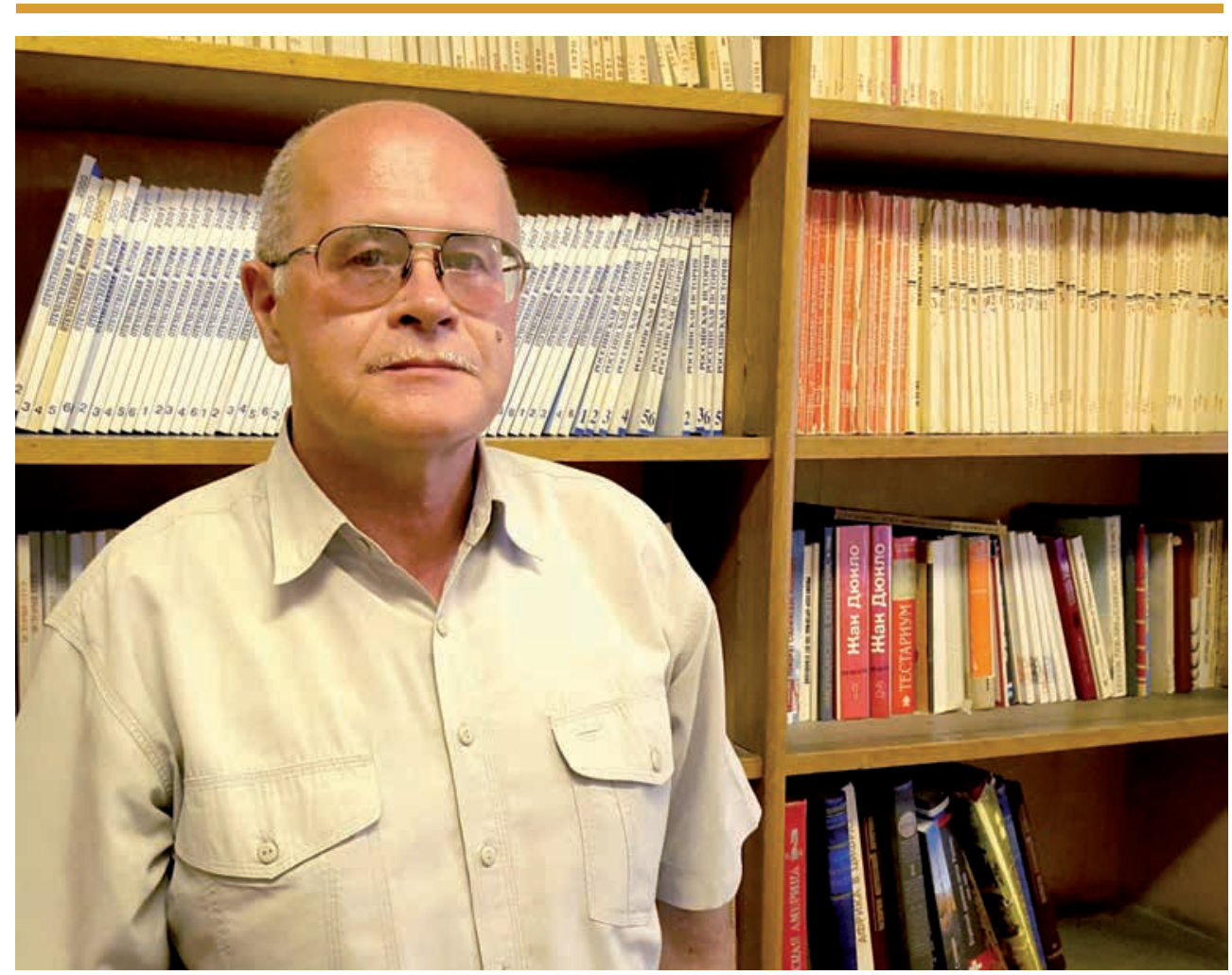

Рис. 1. Вадим Винщерович Трепавлов

Fig. 1. Vadim V. Trepavlov

графию [Овчинникова, 1984; 1990]; руководство Тувинской и Новгородской археологическими экспедициями. В ее лице Вадим Винцерович нашел поддержку и понимание своему школьному увлечению историей Монгольской империи и Золотой Орды. Она направляла его исследовательские начинания во время подготовки курсовых и дипломной работ. Каждое лето, участвуя в руководимой ею Тувинской археологической экспедиции Уральского университета, Вадим Винцерович, тогда юный и начинающий историк-студент, открыл для себя реальный мир азиатских степей.

В 1983 г. Вадим Винцерович окончив университет с отличием стал работать школьным учителем в Свердловске, но желание продолжить начатые в студенческие годы исследова- ния по истории кочевников побудило его продолжить обучение и, проработав год в школе, он поступил в очную аспирантуру московского Института истории СССР АН СССР (ныне Институт российской истории РАН), в отдел общих проблем истории народов СССР (ныне Центр истории народов России и межэтнических отношений). С этого момента и до настоящего времени вся творческая деятельность Вадима Винцеровича всецело посвящена истории кочевых народов Евразии, их взаимоотношениям с Российской империей, межэтническим взаимоотношениям народов Поволжья, Сибири, Северного Кавказа, Центральной Азии.

Научным руководителем кандидатской диссертации Вадима Трепавлова был назначен известный ученый- 
востоковед, заведующий отделом общих проблем истории народов СССР, доктор исторических наук, профессор Сергей Григорьевич Агаджанов (1928-1997) [Милибанд, 2008а, с. 13]. Аспирант Вадим Трепавлов пришел в Институт, твердо зная направление своих исследований - историческая преемственность кочевых империй средневековья, имел некоторые наметки для этого, которые он сделал еще в своей дипломной работе. С. Г. Агаджанов всецело поддержал научные интересы своего нового аспиранта. Много лет спустя В. В. Трепавлов так отзывался о своем научном руководителе: «Стиль его отношений с молодыми коллегами вызывал восхищение и даже зависть у других аспирантов. Он никогда не навязывал своих суждений, полностью доверяя интуиции аспиранта и предлагал внести какието исправления в текст лишь в том случае, если автор писал совсем уж несообразные вещи. Здесь сказывалось не только уважение к труду ученика, но и общая терпимость к чужому мнению, отличающая настоящего интеллигента» [Трепавлов, 2009, с. 311].

\section{Кандидатская}

диссерта-

ция В. В. Трепавлова «Социальнополитическая преемственность в государственном строе Монгольской империи XIII века» [Трепавлов, 1987] была закончена в 1987 г. и успешно защищена в Институте истории СССР 21 января 1988 г. Она стала основой для его первой монографии «Государственный строй Монгольской империи в XIII веке (проблема исторической преемственности)» [Трепавлов, 1993], о которой мы вкратце скажем ниже.

В Институте истории СССР В. В. Трепавлов прошел все ступени карьерного роста, после аспирантуры он работал в должности лаборанта, младшего, старшего, ведущего и главного научного сотрудника, в 1998 г. стал руководителем Центра истории народов России и межэтнических отношений (бывший отдел общих проблем истории народов СССР) [Милибанд, 2008б, с. 497]. В 2001-2003 гг. он одновременно занимал должность заместителя директора Института по научной работе. Административная работа требует много времени и сил, поэтому получив бесценный управленческий опыт, Вадим Винцерович, тем не менее, оставил эту стезю и снова всецело посвятил себя научной деятельности. В 2001 г. он успешно защитил докторскую диссертацию «История Ногайской Орды» [Трепавлов, 2001б], которая ранее в этом же году была опубликована в виде отдельной монографии [Трепавлов, 2001a].

Свой юбилейный рубеж Вадим Винцерович встречает полным сил и энергии как сложившийся ведущий и известный эксперт в мировом кочевниковедении. В его научном арсенале на сегодняшний день более 450 работ. Он является автором 11 монографий и соавтором 18 коллективных трудов (рис. 2). Его статьи публиковались не только в России, но и в научных изданиях Венгрии, Германии, Нидерландов, США, Турции, Узбекистана, Украины, Франции, Швеции, Южной Кореи и Японии. Часто публикуется Вадим Винцерович в Казахстане, иногда случается, что его работы публикуют без его ведома. Такие грустные примеры из нашей «пиратской» эпохи его не сильно огорчают, он отвечает на это новыми статьями и книгами.

В солидном перечне научных работ В. В. Трепавлова лично для меня, как и для многих коллег, большое значение имеют фундаменталь- 


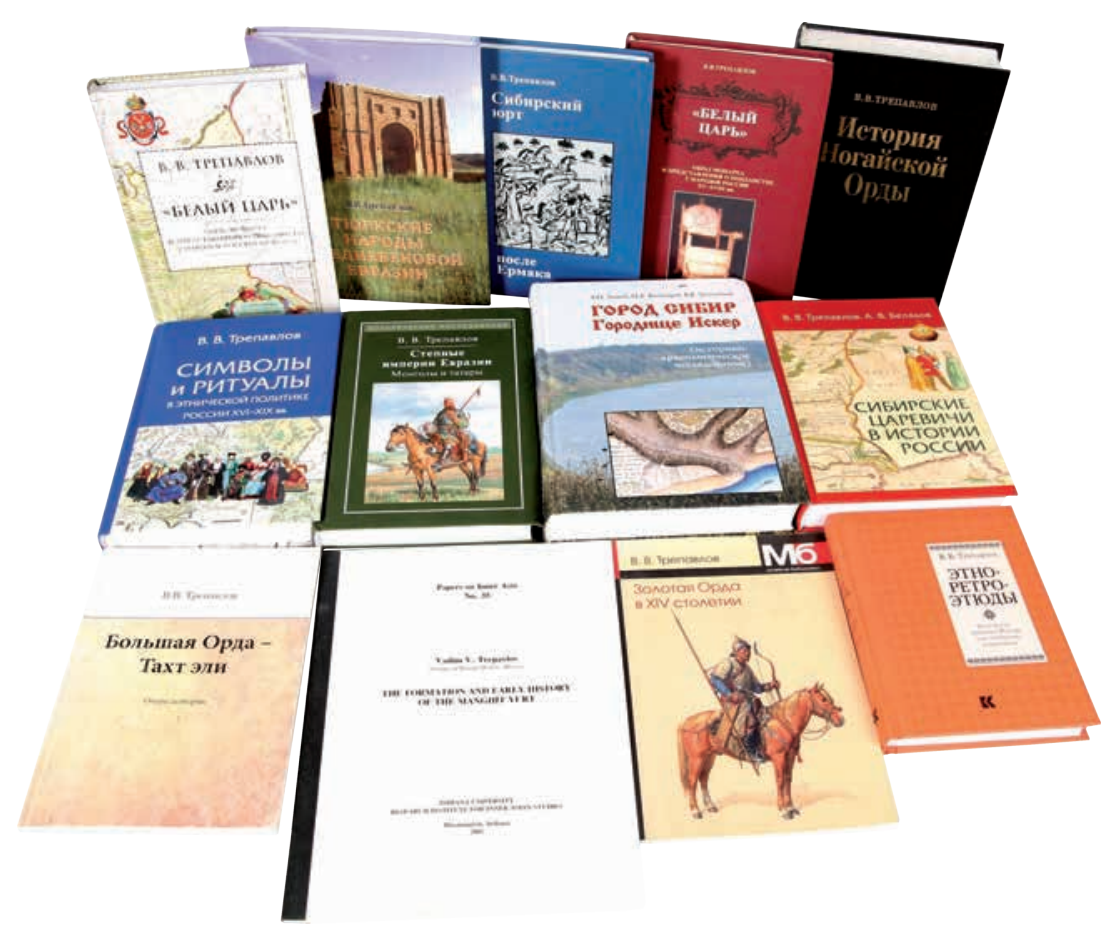

Рис. 2. Научный арсенал В.В. Трепавлова

Fig. 2. The scientific arsenal of V.V. Trepavlov

ные монографические исследования, посвященные истории Монгольской империи, Улуса Джучи, Большой и Ногайской Орд, Сибирского юрта.

Для разных поколений исследователей истории Монгольской империи первая монография В. В. Трепавлова «Государственный строй Монгольской империи XIII веке (проблема исторической преемственности)» [Трепавлов, 1993] вот уже почти 30 лет остается одним из главных источников знаний, прекрасным кладезем ценных сведений и самое главное замечательным образцом действительно научной монографической работы. Некоторые современные исследователи истории Монгольской империи и Золотой Орды часто апеллируют к неким запретам и табу, существовавшим в советской историографии, но не всегда представляют себе суть советских идеологических ограничений в исторической науке. История Монгольской империи и деятельность ее основателя Чингиз-хана тогда продуктивно изучалась, но не всегда получала широкую огласку, оставаясь уделом узких специалистов. Ситуация немного изменилась после появления работ Льва Гумилева [1970] и Евгения Кычанова [1973], но в массовом представлении по-прежнему культивировалась негативная оценка как всей Монгольской империи, так и ее основателя Чингиз-хана. В своей кандидатской диссертации и изданной на ее основе книге В. В. Трепавлов одним из первых в советской литературе именовал это государственное образование Великой Монгольской империей, более того раскрыл вклад Чингиз-хана в создание и организацию новой кочевой империи. По его 
словам, «Монгольская империя (Еке Монгол Улус), завершив историю великих кочевых держав, довела до совершенства механизм объединения номадов, который до того периодически запускался в действие на протяжении полутора тысячелетий» [Трепавлов, 2015, с. 7]. Исследователь справедливо полагает, что историю кочевого мира следует рассматривать не по отдельным империям или эпохам, а как цельный этнокультурный степной мир Евразии. В этом ключе рассмотрен им и государственный строй Монгольской империи. «Монгольская государственность, - пишет автор книги, - развилась на своей собственной основе, явилась плодом общественного развития в Центральной Азии XII - начала XIII в. Но ее форма, в отличие от содержания, была традиционной, т.е. существовала в виде институтов, уже апробированных в кочевых державах раннего Средневековья» [Трепавлов, 1993, с. 113].

Монография В. В. Трепавлова «История Ногайской Орды» сразу же стала главным исследованием по истории этого известного средневекового государства. В ее основу были положены обширные сведения источников из Российского государственного архива древних актов, других российских архивов и библиотек. Автор провел колоссальную исследовательскую работу. История Ногайской Орды это важная и неотъемлемая часть казахской истории, но долгое время в казахской историографии, по справедливому замечанию В. В. Трепавлова, ногайский компонент в развитии казахского народа практически игнорировался [Трепавлов, 2001a, c. 20; 2001б]. Конечно же, казахские историки внесли свой вклад в ногаеведение, и особо В. В. Трепавлов от- метил вклад Амантая Исина [Трепавлов, 2001б, с. 21; 2020, с. 27]. Первое издание «Истории Ногайской Орды» [Трепавлов, 2001б] вместе с последовавшим дополнительным тиражом [Трепавлов, 2002] сразу же стало библиографической редкостью. В 2016 г. книгу переиздали в Казани [Трепавлов, 2016]. Автор дополнил ее новой главой, посвященной Малой Ногайской Орде, которое не вошло в первое издание книги. Словно капля в море и эта книга как будто не появлялась на полках книжных магазинов. В 2020 г. известное московское издательство «Квадрига» опубликовало третье издание [Трепавлов, 2020]. По словам автора книги, оно существенно дополнено по сравнению с первыми двумя. Великолепное знание средневековых русских, восточных и европейских источников, устной традиции кочевников, современной литературы позволило В. В. Трепавлову в «Истории Ногайской Орды» закрыть большой пробел и теперь в историографии ногайского народа есть своя профессионально написанная история Ногайской Орды. Книга была высоко оценена коллегами по всему миру [Зайцев, 2003, с. 187-188; Карpeler, 2003, s. 459-460; Ivanics, 2004, p. 130-136; Кусаинова, 2004, с. 509511; Грибовськиї, 2008, с. 477-488]. В Казахстане она получила широкое признание не только среди историков, но и среди простых любителей истории [Разумов, 2006, с. 68]. По словам медиевиста Амантая Исина, «это наиболее значительный труд в ногаистике» [Исин, 2002, с. 19]. Особо следует отметить, что в этой книге большой и завершающий очерк был посвящен взаимоотношениям ногаев с Россией. Эта тема - история кочевых народов, вошедших в состав России, и их взаи- 
моотношения с Русским государством - на многие годы стала одной из важнейших в научном поиске В. В. Трепавлова.

В 2007 г. вышла новая монография В. В. Трепавлова «“Белый царь”. Образ монарха и представления о подданстве у народов России XVXVIII вв.» [Трепавлов, 2007]. Книга была очень благожелательно встречена читателями и рецензентами [Буганов, 2010, с. 405-409]. В 2017 г. через 10 лет вышло второе, исправленное и дополненное издание [Трепавлов, 2017]. В этой книге автор развивал идею о разном понимании российского подданства официальными властями России и представителями народов, присоединенных к России на протяжении почти четырех столетий, в том числе и казахами; показал «нерусский» взгляд на проблему подданства; на основе источников описал суть этой своеобразной интерпретации подданства кочевниками. Книга содержит ответы на важные вопросы о сути российской государственности, ее преемственности. Автор призывает изучать прошлое народов России не по историософским трактатам и публицистическим статьям, а по адекватным документальным свидетельствам [Трепавлов, 2017, с. 93]. В «Белом царе» В. В. Трепавлов показал себя не только как профессиональный тюрколог-кочевниковед, но и как знаток этнографических материалов, как этнолог, прекрасно знакомый с фактическим материалом с одной стороны и с современными концепциями межэтнического взаимодействия, исторической памяти, формирования идентичностей с другой.

Проблемы отражения межэтнических отношений в образах, обрядах и ментальности народов, населяющих
Россию и сопредельные территории, были продолжены В. В. Трепавловым в новой книге «Символы и ритуалы в этнической политике России XVIXIX вв.» [Трепавлов, 2018]. По мнению казахстанских историков Ануара Галиева и Бахыт Рахимбековой, эта книга обогащает наши знания по теме политического символизма межэтнического взаимодействия в Российской империи и подталкивает к дальнейшим размышлениям и изысканиям [Галиев, Рахимбекова, 2019, с. 332].

Работы В. В. Трепавлова о природе российской власти и ее роли в политической жизни Российской империи значительно расширили диапазон его творческих интересов, но вместе с тем по прежнему важным направлением его научных исследований оставалась политическая и этническая история тюркских народов и государств золотоордынской и постордынской эпохи. Прежде мы говорили об его «Истории Ногайской Орды», позднее вышли книги о Большой Орде [Трепавлов, 2010] и Сибирском юрте [Трепавлов, 2012]. Вышла популярная версия «Истории Ногайской Орды», которая получила свое название: «“Орда самовольная”: Кочевая империя ногаев XV-XVI веков» [Трепавлов, 2013]. Были переизданы наиболее востребованные статьи по истории и культуре тюркских народов средневековой Евразии [Трепавлов, 2011]. Все эти средневековые тюркские государства постордынской эпохи сыграли важную роль в этнической истории казахского народа, политической истории Казахстана. Тему Сибирского ханства в историографический дискурс Казахстана первым включил историк и востоковед Н. Н. Мингулов [1979a, с. 181-187; 1979б, с. 280-282], но история Большой Орды, так же 
как и история Астраханского ханства, по-прежнему остаются вне поля зрения казахстанских исследователей. Попыткой восполнить этот пробел в казахстанской историографии было издание коллективного труда казахстанско-российского авторского коллектива «Большой атлас истории и культуры Казахстана» [Большой атлас, 2008]. Несомненно «яркие» и «добротные» книги В. В. Трепавлова дали не только «связную и логичную историю» этих постордынских государств, но и служат развитию дальнейших исследований в этом направлении [Беляков, 2013, с. 268; Вершинин, 2014, с. 187; Ускенбай, 2012, c. 432].

Большинство коллег знают В. В. Трепавлова как исследователя истории степных империй, кочевых народов и государств, но вместе с тем, как он, шутя говорил при встречах, это лишь его увлечение, хобби, тогда как основная его профессиональная деятельность как научного работника и руководителя Центра истории народов России и межэтнических отношений лежит немного в иной плоскости. Среди таких тем история формирования многонационального Российского государства, национальная политика и межэтнические отношения в России, закономерности функционирования империй и полиэтнических сообществ, история народов России - главным образом Поволжья, Сибири, Северного Кавказа, а также Казахстана и Центральной Азии XIIIXVIII вв., отражение этой истории в памятниках фольклора. Исследованиями всех этих и других вопросов В. В. Трепавлов занимается не один. Под его руководством работает сильный творческий коллектив известных и талантливых ученых, результатом плодотворной работы которого стала серия научных сборников о русских в национальных окраинах России [Русское население, 2000] и Евразии [Русские в Евразии, 2008], Северном Кавказе [Россия и Северный Кавказ, 1998; Война и ислам, 2000] и Среднем Поволжье [Присоединение Среднего Поволжья, 2003], о российской многонациональной цивилизации [Российская многонациональная цивилизация, 2003] и истории окраин и регионов [Национальные, 1998; Образы регионов, 2011] и др. [Российское государство, 2012].

Признанием высоких научных заслуг В. В. Трепавлова является его активная научно-организационная деятельность. Он является экспертом Российского научного фонда, Фонда президентских грантов, Российского фонда фундаментальных исследований, несколько лет входил в состав экспертного совета ВАК РФ по истории; регулярно привлекается органами государственного управления в качестве эксперта для оценки документов, имеющих отношение к истории народов России, бывшего СССР и межэтнических отношений. Долгие годы он входил и входит в составы редколлегий журналов «Российская история», «Этнографическое обозрение», «Вестник Калмыцкого института гуманитарных исследований» (Элиста), «Вестник Удмуртского университета. История и филология» (Ижевск), «Научный Татарстан» (АН Татарстана, Казань), «Золотоордынское обозрение» (Институт истории им. Ш. Марджани АН РТ, Казань), «Волго-Уральские региональные исследования» (Приволжский федеральный университет, Казань), «Тюркологические исследования» (Приволжский федеральный университет, Казань), «Гасырлар 
авазы=Эхо веков» (Главное архивное управление при Кабинете Министров Республики Татарстан, Казань), электронного журнала «Scriptorum Nostrum» (Херсонский университет, Украина); является ответственным редактором периодического издания возглавляемого им Центра «История народов России в исследованиях и документах»; много лет был в числе ответственных редакторов авторитетного «Тюркологического сборника».

В. В. Трепавлов пользуется заслуженным авторитетом среди коллег. Его достижения в области изучения прошлого народов России и Евразии признаны российскими и зарубежными коллегами. Репутация объективного и непредвзятого исследователя (особенно необходимая при изучении такой деликатной сферы, как этническая история и межэтнические отношения) получила и общественное признание. За последние годы ученый был неоднократно награжден. Он стал Заслуженным деятелем науки Карачаево-Черкесской Республики, лауреатом Государственной премии Республики Татарстан в области науки и техники, премии им. Хусаина Фаизханова и др. Особенно юбиляр ценит специально изготовленный знак «Народное признание», который представители ногайской общественности вручили ему от имени ногайского народа в 2019 г.

Мое знакомство с творчеством Вадима Винцеровича началось еще в студенческие годы. Будучи аспирантом, я пытался установить с ним связь, но в конце 1990-х и начале 2000-х годов обычная почта работала плохо, а электронная только появлялась. В это же время из Алматы в Москву переехал доктор исторических наук Александр Шайдатович Кадырбаев, через него я и мой коллега Нурлан Атыгаев смогли передать Вадиму Винцеровичу свои первые опубликованные статьи и письмо с адресом электронной почты. Сколько было радости, когда мы получили ответное письмо от В. В. Трепавлова с предложением научного сотрудничества. В. В. Трепавлов как один из составителей и редакторов возобновленного «Тюркологического сборника» предложил нам в нем опубликоваться. Наши статьи стали первыми после его возобновления публикациями казахстанских авторов в этом престижном академическом издании [Ускенбай, 2006, с. 353-380; Атыгаев, 2007, с. 50-61]. Наше научное сотрудничество продолжается и по сей день. В 2008 г. в Алматы издательство АО «АБДИ Компани» опубликовало «Большой атлас истории и культуры Казахстана» [Большой атлас, 2008], для которого В. В. Трепавлов написал несколько глав. В 2013 г. в германском Бохуме вышла наша с ним совместная статья на немецком языке «Dašt-i Kipčak im ethnohisorischen Raum Eurasiens im 12.-16. Jh.» [Trepavlov, Uskenbay, 2013]. В 2012 г. с любезного разрешения покойного Томаса Олссена (1940-2019) мы опубликовали совместный перевод его статьи «Царевичи левой руки: введение в историю улуса Орды» [Олссен, 2012, с. 209-228]. В 2013 г. Вадим Винцерович выступил рецензентом моей монографии «Восточный Дашт-и Кыпчак в XIII - начале XV века. Проблемы этнополитической истории Улуса Джучи» [Ускенбай, 2013]. Уверен, наше плодотворное научное сотрудничество с Вадимом Винцеровичем продолжится и в будущем. Значение его трудов для историографии Казахстана сложно переоценить, но уже сейчас можно сказать, что в нашем 
евразийском кочевниковедении есть свой «Менделеев» - образец порядочности, интеллигентности, скромности, высокого служения науке. Горячо поздравляем Вадима Винцеровича Трепавлова с юбилеем и желаем ему новых творческих успехов, благополучия и крепкого здоровья. А завершить наш короткий очерк хочется очень актуальными словами самого юбиляра о профессионализме в истории: «При анализе событий прошлого желательно пытаться уходить от всяческих пристрастий - политических, этнических и пр. Пример последних полутора десятилетий показывает, что «этнически ориентированная» наука оставляет убогое впечатление. На этом поприще нет и не может быть научного прогресса, поэтому процветают домыслы и фальсификации. Болееменее понятно, когда авторами таких сочинений движут соображения заработка или карьеры. Но историки, искренне исповедующие этноцентризм, - это жалкое зрелище. За время моей работы в науке я много раз убеждался: чем больше человек зациклен на величии истории исключительно своего народа, тем менее он профессионален как историк» [Трепавлов, 2004].

\section{ЛИТЕРАТУРА}

1. Атылаев Н.А. Хронология правления казахских ханов (XV - середина XVI в.) // Тюркологический сборник-2006. М.: Вост. лит., 2007. С. 50-61.

2. Беляков А.В. [Рец. на кн.:] Трепавлов В.В. Сибирский юрт после Ермака: Кучум и Кучумовичи в борьбе за реванш. М.: Восточная литература, 2012. 231 с. // Вестник Российского гуманитарного научного фонда. 2013. № 4 (130). С. 263-269.

3. Большой атлас истории и культуры Казахстана. Алматы: АБДИ Компани, $2008.880 \mathrm{c}$.

4. Буганов A.B. О русском царе и российском менталитете // История и историки: историографический вестник. 2008. М.; Тула: Гриф и К, 2010. С. 405-409.

5. Вериинин Е.В. [Рец. на кн.:] В.В. Трепавлов. Сибирский юрт после Ермака. Кучум и Кучумовичи в борьбе за реванш. М.: Восточная литература, 2012. 232 с. // Российская история. 2014. № 3. С. 184-187.

6. Война и ислам на Северном Кавказе XIX-XX вв. М.: Инст. росс. ист. РАН, 2000. 54 c.

7. Галиев А., Рахимбекова Б. [Рец. на кн.:] В.В. Трепавлов. Символы и ритуалы в этнической политике России XVI-XIX вв. СПб.: Изд-во О. Абышко, 2018. 320 с. // Ab Imperio. 2019. № 1. C. 326-332.

8. Ганиев P.T., Соловьева B.B., Сазанова А.В. Наш учитель // Бронислава Борисовна Овчинникова. Биобиблиография. Сост.: Я. Питнер. Екатеринбург: Банк культурной информации, 2012. С. 10-21.

9. Грибовськиї В. Кочівницьки імперії та політичні репрезентації ногайцїв в «Історії Ногайскої Орди» В.В. Трепавлова // Эйдос. 2008. Вип. 3. Ч. 1. С. 477-488.

10. Гумилев Л.Н. Поиски вымышленного царства: (Легенда о «Государстве 'пресвитера Иоанна'»). М.: Наука, 1970. 431 с.

11. Зайщев И.В. [Рец. на кн.:] Трепавлов В.В. История Ногайской Орды. М.: Вост. лит., 2001. 752 с. // Восток. 2003. № 3. С. 187-188.

12. Исин А. Казахское ханство и Ногайская Орда во второй половине XV-XVI в. Семипалатинск: Тенгри, 2002. 139 с.

13. Кусаинова Е.В. [Рец. на кн.:] Трепавлов В.В. История Ногайской Орды. М.: Вост. лит., 2001. 752 с. // Стрежень. Научный ежегодник. 2004. Вып. 4. С. 509-511. 
14. Кычанов Е.И. Жизнь Темучжина, думавшего покорить мир. М.: Наука, Гл. ред. вост. лит., 1973. 144 с.

15. Милибанд С.Д. Востоковеды России: XX - начало XXI в.: биобиблиографический словарь: в 2 кн. М.: Вост. лит., 2008а. Кн. I: А-М. 968 с.

16. Милибанд С.Д. Востоковеды России: XX - начало XXI в.: биобиблиографический словарь: в 2 кн. М.: Вост. лит., 2008б. Кн. ІІ: Н-Я. 1005 с.

17. Мингулов Н.Н. Ногайская Орда, Северный Казахстан и Западная Сибирь во второй половине XIII-XV веках // История Казахской ССР (с древнейших времен до наших дней). В пяти томах. Алма-Ата: Наука, 1979а. Т. II. С. 181-187.

18. Мингулов Н.Н. Сибирское ханство при Кучуме // История Казахской ССР (с древнейших времен до наших дней). В пяти томах. Алма-Ата: Наука, 1979б. Т. II. C. $280-282$.

19. Национальные окраины Российской империи. Становление и развитие системы управления. М.: Славянский диалог, 1998. 416 с.

20. Образы регионов в общественном сознании и культуре России (XVIIХІХ вв.). Тула: Гриф и К, 2011. 352 с.

21. Овчинникова Б.Б. Тюрки-тугю на Саяно-Алтайском нагорье в VI-X вв. (по материалам погребений человека с конем): автореф. дис. ... канд. ист. наук. М.: МГУ им. М.В. Ломоносова, 1984. 22 с.

22. Овчинникова Б.Б. Тюркские древности Саяно-Алтая в VI-X веках. Свердловск: Изд-во УрГУ, 1990. 222 с.

23. Олссен T.T. Царевичи левой руки: введение в историю улуса Орды ХІІІ начала XIV века // Золотоордынская цивилизация: сб. ст. Казань: ООО «Фолиант»; Институт истории им. Ш. Марджани АН РТ, 2012. Вып. 5. С. 209-228.

24. Присоединение Среднего Поволжья к Российскому государству. Взгляд из XXI века. Материалы круглого стола в Институте российской истории РАН (г. Москва, 14 ноября 2002 г.). М.: Инст. росс. ист. РАН, 2003. 38 с.

25. Разумов Я. О книге Вадима Трепавлова «История Ногайской Орды» // Эксклюзив. 2006. № 3 (36). С. 68.

26. Российская многонациональная цивилизация. Единство и противоречия. М.: Наука, 2003. 378 c.

27. Российское государство от истоков до XIX века: территория и власть. М.: РОССПЭН, 2012. $462 \mathrm{c.}$

28. Россия и Северный Кавказ: 400 лет войны? М.: Инст. росс. ист. РАН, 1998. $37 \mathrm{c}$.

29. Русские в Евразии XVII-XIX вв. Миграции и социокультурная адаптация в иноэтничной среде. М.; Тула: Гриф и К, 2008. 480 с.

30. Русское население национальных окраин России XVII-XX вв. М.: Славянский диалог, 2000. 320 с.

31. Трепавлов В.В. Социально-политическая преемственность в государственном строе Монгольской империи XIII в.: автореф. дис. ... канд. ист. наук. М.: Институт истории СССР, 1987. 16 с.

32. Трепавлов В.В. Государственный строй Монгольской империи XIII в.: Проблема исторической преемственности. М.: Наука. Вост. лит., 1993. 168 с.

33. Трепавлов В.В. История Ногайской Орды. М.: Вост. лит., 2001 а. 752 с.

34. Трепавлов В.В. История Ногайской Орды. Докт. дис. М., 2001б. 662 л.

35. Трепавлов В.В. История Ногайской Орды. М.: Вост. лит., 2002. 752 с.

36. Трепавлов В.В. «Отбрасывать драгоценное наследие российской тюркологии это непростительное расточительство». Интервью Рустаму Абдуманапову. Томск;

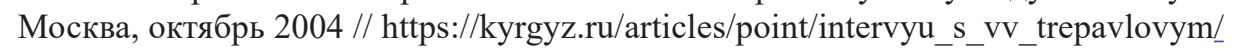

37. Трепавлов В.В. «Белый царь». Образ монарха и представления о подданстве у народов России XV-XVIII вв. М.: Вост. лит., 2007. 255 с. 
38. Tрепавлов B.B. Сергей Григорьевич Агаджанов (к 80-летию со дня рождения) // История и историки: историографический вестник. 2007. М.: Наука, 2009. C. $309-315$.

39. Трепавлов В.В. Большая Орда - Тахт эли. Очерк истории. Тула: Гриф и К, 2010. $112 \mathrm{c}$.

40. Трепавлов В.В. Тюркские народы средневековой Евразии. Избранные труды. Казань: Фолиант, 2011. 252 с.

41. Трепавлов B.B. Сибирский юрт после Ермака: Кучум и Кучумовичи в борьбе за реванш. М. : Вост. лит., 2012. 231 с.

42. Трепавлов В.В. «Орда самовольная»: Кочевая империя ногаев XV-XVI веков. М.: Квадрига, 2013. 224 с.

43. Трепавлов B.B. Степные империи Евразии: монголы и татары. М.: Квадрига, $2015.368 \mathrm{c}$.

44. Трепавлов В.В. История Ногайской Орды. 2-е изд., испр. и доп. Казань: Казанская недвижимость, 2016. 764 с.

45. Трепавлов B.B. «Белый царь». Образ монарха и представления о подданстве у народов России XV-XVIII вв. 2-е изд, испр. и доп. СПб: Изд-во Олега Абышко, 2017. $320 \mathrm{c}$.

46. Трепавлов В.В. Символы и ритуалы в этнической политике России XVIХІХ вв. СПб: Изд-во Олега Абышко, 2018. 320 с.

47. Трепавлов B.В. История Ногайской Орды. 3- изд., испр. и доп. М.: Квадрига, 2020. $1040 \mathrm{c}$.

48. Ускенбай К.3. Улусы первых Джучидов. Проблема терминов Ак-Орда и Кок-Орда // Тюркологический сборник / 2005: Россия и Великая Степь. М.: Вост. лит., 2006, с. 353-380.

49. Ускенбай К.3. [Рец. на кн.:] Трепавлов В.В. Большая Орда - Тахт эли. Очерк истории. Тула: «Гриф и К», 2010. 112 с. // Золотоордынская цивилизация. Сб. ст. Вып. 5. Казань: ООО «Фолиант»; Институт истории им. Ш. Марджани АН РТ, 2012. C. 429-432.

50. Ускенбай К.3. Восточный Дашт-и Кыпчак в XIII - начале XV века. Проблемы этнополитической истории Улуса Джучи. Казань: Изд-во «Фэн» АН РТ, 2013. 289 с.

51. Ivanics M. [Рец. на кн.:] Трепавлов В.В. История Ногайской Орды. М.: Вост. лит., 2001. 752 с. // Acta orientalia Akademiae scientiarum hungaricae. Budapest, 2004. Vol. 57. № 1. P. 130-136.

52. Kappeler A. [Рец. на кн.:] Трепавлов В.В. История Ногайской Орды. М.: Вост. лит., 2001. 752 с. // Jahrbücher für Geschichte Ost-Europas (Wiesbaden). 2003. В. 51. S. $459-460$.

53. Trepavlov V., Uskenbay K. Dašt-i Kipčak im ethnohisorischen Raum Eurasiens im 12.-16. Jh. // Unbekanntes Kasachstan. Archäologie im Herzen Asiens. Band II. Katalog der Ausstellung des Deutschen Bergbau-Museum Bochum vom 26. Herausgeber: T. Stöllner, Z. Samašev. Unter Mitarbeit von: A. Gorelik, G. Körlin. Bochum: Deutsches BergbauMuseum Bochum, 2013. S. 889-901.

\section{REFERENCES}

1. Atygaev, N. A. 2007. In: Tyurkologicheskiy sbornik - 2006 (Turkological collection - 2006). Moscow: "Vostochaya literatura" Publ., 50-61 (in Russian).

2. Belyakov, A. V. 2013. In: Vestnik Rossijskogo gumanitarnogo nauchnogo fonda (Bulletin of the Russian Humanitarian Science Foundation), 4 (130), 263-269 (in Russian).

3. Bolshoy atlas istorii i kultury Kazahstana. 2008 (Large Atlas of History and Culture of Kazakhstan). Almaty: “ABDI Kompany” Publ. (in Russian). 
4. Buganov, A. V. 2010. In: Istoriya i istoriki: istoriograficheskij vestnik. 2008 (History and historians: historiographic bulletin. 2008). Moscow; Tula: "Grif i K” Publ. 405409 (in Russian).

5. Vershinin, E. V. 2014. In: Rossijskaya istoriya (Russian history), 3, 184-187 (in Russian).

6. Vojna i islam na Severnom Kavkaze XIX-XX vv. 2000 (War and Islam in the North Caucasus in the 19th - 20th centuries). Moscow: Institute of Russian History Publ. (in Russian).

7. Galiev, A., Rahimbekova, B. 2019. In: Ab Imperio. 1. 326-332 (in Russian).

8. Ganiev, R. T., Solov'eva, V. V., Sazanova, A. V. 2012. In: Bronislava Borisovna Ovchinnikova. Biobibliografiya (Bronislava B. Ovchinnikova. Biobibliography). Ekaterinburg: "Bank kul'turnoj informacii" Publ. 10-21 (in Russian).

9. Gribovs'kiï, V. 2008. In: Ejdos, 3.1, 477-488 (in Russian).

10. Gumilev, L. N. 1970. Poiski vymyshlennogo carstva: (Legenda o "Gosudarstve 'presvitera Ioanna'») (Quest for a Fictional Kingdom: (The Legend of the 'Presbyter John' State). Moscow: "Nauka" Publ. (in Russian).

11. Zajcev, I. V. 2003. In: Vostok. 3. 187-188 (in Russian).

12. Isin, A. 2002. Kazahskoe hanstvo i Nogajskaya Orda vo vtoroj polovine $X V-$ $X V I$ v. (Kazakh Khanate and Nogai Horde in the second half of the XV-XVI centuries) Semipalatinsk: “Tengri” Publ. (in Russian).

13. Kusainova, E. V. 2004. In: Strezhen'. Nauchnyj ezhegodnik (Strezhen'. Scientific Yearbook). Vol. 4. 509-511 (in Russian).

14. Kychanov, E. I. 1973. Zhizn' Temuchzhina, dumavshego pokorit'mir (The life of Temujin, who thought to conquer the world). Moscow: "Nauka, Gl. red. "Vost. lit." Publ. (in Russian).

15. Miliband, S. D. 2008a. Vostokovedy Rossii: XX - nachalo XXI v.: biobibliograficheskij slovar': v $2 \mathrm{kn}$. (Orientalists of Russia: XX - early XXI century: biobibliographic dictionary: in 2 books) Moscow: "Vost. lit." Publ. Book I (in Russian).

16. Miliband, S. D. 2008b. Vostokovedy Rossii: XX - nachalo XXI v.: biobibliograficheskij slovar': v $2 \mathrm{kn}$. (Orientalists of Russia: XX - early XXI century: biobibliographic dictionary: in 2 books) Moscow: Vost. lit., Publ. Book II (in Russian).

17. Mingulov, N. N. 1979a. In: Istoriya Kazahskoj SSR (s drevnejshih vremen do nashih dnej). V pyati tomah (History of the Kazakh SSR (from ancient times to the present day). In five volumes.), vol. II. Alma-Ata: "Nauka" Publ., 181-187 (in Russian).

18. Mingulov, N. N. 1979b. In: Istoriya Kazahskoj SSR (s drevnejshih vremen do nashih dnej). V pyati tomah (History of the Kazakh SSR (from ancient times to the present day). In five volumes.), vol. II. Alma-Ata: "Nauka" Publ., 280-282 (in Russian).

19. Nacional'nye okrainy Rossijskoj imperii. Stanovlenie $i$ razvitie sistemy upravleniya. 1998 (National outskirts of the Russian Empire. Formation and development of the management system). Moscow: "Slavyanskij dialog" Publ. (in Russian).

20. Obrazy regionov vobshchestvennom soznanii i kul ture Rossii (XVII-XIXvv.). 2011 (Images of regions in the public consciousness and culture of Russia (XVII-XIX centuries)). Tula: "Grif i K" Publ. (in Russian).

21. Ovchinnikova, B. B. 1984. Tyurki-tugyu na Sayano-Altajskom nagor'e v VI-Xvv. (po materialam pogrebenij cheloveka s konem): avtoref. dis. kand. ist. nauk (Türks-tugyu in the Sayano-Altai upland in the 6th-10th centuries (based on the materials of the burials of a man with a horse): abstract of the dissertation of the candidate of historical sciences). Moscow: M. V. Lomonosov Moscow State University Publ. (in Russian).

22. Ovchinnikova, B. B. 1990. Tyurkskie drevnosti Sayano-Altaya v VI-X vekah (Turkic antiquities of Sayan-Altai in the 6th-10th centuries). Sverdlovsk: "UrGU" Publ. (in Russian). 
23. Allsen, T. T. 2012. In: Zolotoordynskaya civilizaciya: sb. st. (Golden Horde civilization: collection of articles), vol. 5. Kazan: "Foliant" Publ.; Sh. Mardzhani Institute of History, 209-228 (in Russian).

24. Prisoedinenie Srednego Povolzh'ya k Rossijskomu gosudarstvu. Vzglyad iz XXI veka. 2003 (Accession of the Middle Volga region to the Russian state. A look from the XXI century). Moscow: Institute of Russian History Publ. (in Russian).

25. Razumov, Ya. 2006. In Exclusive, 3 (36), 68 (in Russian).

26. Rossijskaya mnogonacionalnaya civilizaciya. Edinstvo i protivorechiya. 2003 (Russian multinational civilization. Unity and contradiction). Moscow: "Nauka" Publ. (in Russian).

27. Rossijskoe gosudarstvo ot istokov do XIX veka: territoriya i vlast'. 2012 (The Russian state from its origins to the 19th century: territory and power). Moscow: ROSSPEN Publ. (in Russian).

28. Rossiya i Severnyj Kavkaz: 400 let vojny? 1998 (Russia and the North Caucasus: 400 Years of War?). Moscow: Institute of Russian History Publ. (in Russian).

29. Russkie v Evrazii XVII-XIX vv. Migracii $i$ sociokul'turnaya adaptaciya $v$ inoetnichnoj srede. 2008 (Russians in Eurasia, 17th - 19th centuries. Migration and sociocultural adaptation in a different ethnic environment). Moscow; Tula: "Grif i K" Publ. (in Russian).

30. Russkoe naselenie nacional'nyh okrain Rossii XVII-XX vv. 2000 (Russian population of the national outskirts of Russia in the 17th - 20th centuries). Moscow: Slavyanskij dialog Publ. (in Russian).

31. Trepavlov, V. V. 1987. Social'no-politicheskaya preemstvennost' $v$ gosudarstvennom stroe Mongol'skoj imperii XIII v.: avtoref. dis. kand. ist. nauk (Sociopolitical continuity in the state system of the Mongolian empire of the 13th century: abstract of the dissertation of the candidate of historical sciences). Moscow: Institute of Russian History Publ. (in Russian).

32. Trepavlov, V. V. 1993. Gosudarstvennyj stroj Mongol'skoj imperii XIII v.: Problema istoricheskoj preemstvennosti (The State System of the Mongol Empire in the XIII Century: The Problem of Historical Continuity). Moscow: "Nauka", "Vost. lit." Publ. (in Russian).

33. Trepavlov, V. V. 2001a. Istoriya Nogajskoj Ordy (History of the Nogai Horde). Moscow: Vost. lit. Publ. (in Russian).

34. Trepavlov, V. V. 2001b. Istoriya Nogajskoj Ordy (History of the Nogai Horde). Doctoral dissertation. Moscow (in Russian).

35. Trepavlov, V. V. 2002. Istoriya Nogajskoj Ordy (History of the Nogai Horde). Moscow: Vost. lit. Publ. (in Russian).

36. Trepavlov, V. V. 2004. In: https://kyrgyz.ru/articles/point/intervyu_s_vv_ trepavlovym/ (in Russian).

37. Trepavlov, V. V. 2007. «Belyj car'». Obraz monarha i predstavleniya o poddanstve u narodov Rossii XV-XVIII vv. ("White Tsar". The image of the monarch and the idea of citizenship among the peoples of Russia in the 15th - 18th centuries). Moscow: "Vost. lit." Publ. (in Russian).

38. Trepavlov, V. V. 2009. In Istoriya i istoriki: istoriograficheskij vestnik. 2007 (History and historians: historiographic bulletin. 2007). Moscow: "Nauka" Publ., 309-315 (in Russian).

39. Trepavlov, V. V. 2010. Bol'shaya Orda - Taht eli. Ocherk istorii (Big HordeTaqt eli. History sketch). Tula: "Grif i K" Publ. (in Russian).

40. Trepavlov, V. V. 2011. Tyurkskie narody srednevekovoj Evrazii. Izbrannye trudy (Turkic peoples of medieval Eurasia. Selected Works). Kazan: "Foliant” Publ. (in Russian). 
41. Trepavlov, V. V. 2012. Sibirskij yurt posle Ermaka: Kuchum i Kuchumovichi $v$ bor'be za revansh (Siberian yurt after Yermak: Kuchum and Kuchumovich in the fight for revenge). Moscow: "Vost. lit." Publ. (in Russian).

42. Trepavlov, V. V. 2013. «Orda samovol'naya»: Kochevaya imperiya nogaev $X V-X V I$ vekov ("Unauthorized Horde": Nomadic Empire of the Nogai XV-XVI centuries). Moscow: "Kvadriga" Publ. (in Russian).

43. Trepavlov, V. V. 2015. Stepnye imperii Evrazii: mongoly i tatary (Steppe Empires of Eurasia: Mongols and Tatars). Moscow: "Kvadriga" Publ. (in Russian).

44. Trepavlov, V. V. 2016. Istoriya Nogajskoj Ordy (History of the Nogai Horde). Second edition revised and enlarged. Kazan: "Kazanskaya nedvizhimost" Publ. (in Russian).

45. Trepavlov, V. V. 2017. «Belyj car'». Obraz monarha i predstavleniya o poddanstve $u$ narodov Rossii $X V-X V I I I v v$. ("White Tsar". The image of the monarch and the idea of citizenship among the peoples of Russia in the 15th-18th centuries). Second edition revised and enlarged. Saint Petersburg: Oleg Abyshko Publ. (in Russian).

46. Trepavlov, V. V. 2018. Simvoly i ritualy v etnicheskoj politike Rossii XVI-XIXvv. (Symbols and rituals in the ethnic policy of Russia in the 16th - 19th centuries.). Saint Petersburg: Oleg Abyshko Publ. (in Russian).

47. Trepavlov, V. V. 2020. Istoriya Nogajskoj Ordy (History of the Nogai Horde). Third edition revised and expanded. Moscow: "Kvadriga" Publ. (in Russian).

48. Uskenbay, Q. Z. 2006. In: Tyurkologicheskij sbornik-2005: Rossiya i Velikaya Step'. (Turkological collection - 2005: Russia and the Great Steppe). Moscow: "Vost. lit." Publ. 353-380 (in Russian).

49. Uskenbay, Q. Z. 2012. In: Zolotoordynskaya civilizaciya: sb. st. (Golden Horde civilization: collection of articles). Vol. 5. Kazan: «Foliant» Publ.; Sh. Mardzhani Institut of History, 429-432 (in Russian).

50. Uskenbay, Q. Z. 2013. Vostochnyj Dasht-i Kypchakv XIII-nachale XV veka. Problemy etnopoliticheskoj istorii Ulusa Dzhuchi (Eastern Dasht-i Qypchaq in the XIIIearly XV century. Problems of the ethnopolitical history of Ulus Jochi). Kazan: "Fen" Publ. (in Russian).

51. Ivanics, M. 2004. In: Acta orientalia Akademiae scientiarum hungaricae, 57.1, $130-136$.

52. Kappeler, A. 2003. In Jahrbücher für Geschichte Ost-Europas, 51, 459-460.

53. Trepavlov, V. V., Uskenbay Q. 2013. In: Unbekanntes Kasachstan. Archäologie im Herzen Asiens. Band II. Katalog der Ausstellung des Deutschen Bergbau-Museum Bochum vom 26. Herausgeber: T. Stöllner, Z. Samašev. Unter Mitarbeit von: A. Gorelik, G. Körlin. Bochum: Deutsches Bergbau-Museum Bochum, 889-901. 